\title{
Surgical research in the north and northeast of Brazil ${ }^{1}$
}

\author{
Rafael Silva de Araújo ${ }^{I}$, Felipe Nunes Brito ${ }^{I I}$, Yan Chaves ${ }^{I I}$, Daniela Francescato Veiga ${ }^{\text {IV }}$, Lydia Masako Ferreira ${ }^{\mathrm{V}}$ \\ 'Undergraduate student, Medical School, UEPA, Belem-PA, Brazil. Acquisition, analysis and interpretation of data; manuscript critical revision. \\ "Undergraduate student, Medical School, UFPA, Belem-PA, Brazil. Acquisition, analysis and interpretation of data; manuscript critical revision. \\ "IIUndergraduate student, Medical School, UFPB, Joao Pessoa-PB, Brazil. Acquisition, analysis and interpretation of data; manuscript critical revision. \\ ${ }^{\text {IV }} \mathrm{PhD}$, Associate Professor, Plastic Surgery Division, UNIFESP, Sao Paulo-SP. Associate Professor, Plastic Surgery Division, UNIVÁS, Pouso Alegre- \\ MG, Brazil. Analysis and interpretation of data, manuscript writing, critical revision. \\ ${ }^{v}$ PhD, Full Professor, Head of Plastic Surgery Division, UNIFESP, Sao Paulo-SP, Brazil. Coordinator Medicine III CAPES; Researcher 1B CNPq, \\ Coordinator Medicine Committee CNPq. Conception, design, intellectual and scientific content of the study, manuscript writing and critical revision.
}

\section{ABSTRACT}

PURPOSE: To evaluate the scientific production from the surgical areas from the State University of Para (UEPA), Federal Universities of Para (UFPA) and of Paraiba (UFPB), Brazil.

METHODS: The scientific productions of professors in the last five years were classified according to the Qualis system of CAPESMedicine III (http://qualis.capes.gov.br/webqualis/publico/pesquisaPublicaClassificacao.seam?conversationPropagation=begin) and it was computed the number of guidance of students scientific projects.

RESULTS: Seventy-four professors were included, 31 with Master and 43 with PhD degrees. UFPA presented more publications (49\% out of the total), which $32 \%$ of them in Journals B1 or higher. Otorhinolaryngology presented the greatest number of publications (29\% out of the total); however, $98 \%$ of them in B3 or lower. Gastroenterological Surgery, which is responsible for $23 \%$ out of the total, had $57 \%$ of its publications in B1 or higher. The most frequent type of guidance was the one about scientific work of completion of undergraduate course (63\%). Gynecology and Obstetrics presented the greatest number of student's guidance (35\% out of the total) and Gastroenterological Surgery the largest number of Master's degree and $\mathrm{PhD}$ degree supervisions.

CONCLUSIONS: The specialties Gynecology and Obstetrics and Gastroenterological Surgery from the State University of Para (UEPA), Federal Universities of Para (UFPA) and of Paraiba (UFPB) presented the greatest number of professors with academic degrees. Gastroenterological Surgery presented the largest scientific productions at higher strata of WebQualis CAPES classification and also the largest number of Master and $\mathrm{PhD}$ directed.

Key words: Academic Medical Centers. Faculty, Medical. Program Accreditation. General Surgery. Research. 


\section{Introduction}

Medical education in Brazil began with the creation of the Medical Surgery Course of Bahia in 1808, which evolved to the current Federal University of Bahia (UFBA) ${ }^{1}$. In spite of the geographic proximity, only after 111 years the North Region was inserted in the scenario of the national medical teaching, with the creation of the School of Medicine and Surgery of Para in 1919, subsequently integrated to the Federal University of Para (UFPA) ${ }^{2}$. In Paraiba, the School of Medicine, Odontology and Pharmacy was created in 1950, and, in 1955, it was integrated to the Federal University of Paraiba (UFPB). Higher education teaching in Brazil evolved and, since the university reform, Brazil has gained space in the worldwide scientific production ${ }^{3}$. In the last years, the quantity of published scientific articles in indexed journals increased less than $9 \%$ in the world, while Brazil had an increase of approximately $54 \%$ in its publication number ${ }^{4}$.

In Medicine and specifically in the surgical field, the State of Sao Paulo was a pioneer in the creation of graduate programs (Master and $\mathrm{PhD}$ ) in the surgical area ${ }^{5}$. However, after roughly 50 years, actions to reduce the asymmetries of North, Northeast and Central-West are still necessary, particularly about graduate programs in several axes, such as: area of expertise, quality, quantity and distribution of concepts of the programs established by the evaluation of the Coordination of Improvement for Higher Academic Staff (CAPES) ${ }^{6}$.

There are papers that report a high concentration of Schools of Medicine in the State of Sao Paulo compared to the national $\operatorname{set}^{7}$. The asymmetries are also reported as in the certification scope of the faculty as in the scientific production scope, among the various Brazilian institutions ${ }^{8}$.

Despite the relevance of the topic, there is a shortage of studies and surveys about the certification and production of professors in the surgical field in Brazil has motivated the present study regarding academic degree and scientific production of professors in the surgical areas in the Federal and State University of Para and Federal University of Paraiba. The purpose is to investigate the academic reality of some public universities in the North and Northeast in Brazil.

\section{Methods}

A listing containing the professors from the surgical area (defined by the specialties that compose the area Medicine III of CAPES from three public universities (State University of Para UEPA, Federal University of Para - UFPA, Federal University of
Paraiba - UFPB) and their respective academic degree obtained. The "surgical area" was defined by the surgical specialties that compose the area Medicine III of CAPES and the nomenclature adopted in the table CAPES' areas of scientific knowledge (available in http://capes.gov.br/avaliacao/tabela-de-areas-deconhecimento). Subspecialties which are not in the table, such as Oncology Surgery and General Surgery, were grouped in the term "Surgery" that is in the table.

A research was conducted in the Lattes platform of $\quad \mathrm{CNPq} \quad$ (http://buscatextual.cnpq.br/buscatextual/busca. do?metodo=apresentar) in order to obtain the curriculum of every professor who had Master's and PhD degrees and the ones who had their Lattes curriculum updated less than three years ago were included in the study. Professors without Academic degree and those ones who do not have their Lattes curriculum updated were excluded.

The production of professors in the last five years (2008 to 2012) was obtained from the Lattes platform and it was classified according to Qualis of the area Medicine III of CAPES (available in: http://www.capes.gov.br/component/content/ article/44-avaliacao/4633-medicina III) (Table 1).

TABLE 1 - Web Qualis Medicine III of CAPES (2010 and 2011).

\begin{tabular}{cc}
\hline Level & Criteria \\
\hline A1 & Impact factor $\geq \mathbf{3 . 3 0}$ (Journals of the Medicine III Area) \\
A2 & Impact factor $=\mathbf{2 . 6 3}-\mathbf{3 . 2 9}$ \\
B1 & Impact factor $=\mathbf{1 . 5 0}-\mathbf{2 . 6 2}$ \\
B2 & Impact factor $=\mathbf{0 . 9 0}-\mathbf{1 . 4 9}$ \\
B3 & Impact factor $=\mathbf{0 . 0 1}-\mathbf{0 . 8 9}$ \\
B4 & Journals of the Medicine III Area indexed in other \\
B5 & Journals outside the Medicine III Area indexed in other \\
\hline
\end{tabular}

It was also evaluated the number of guidance of undegraduate and graduate students. The professors were stratified by their specialty and the obtained data were subjected to a statistical analysis. The absolute and relative frequencies of the studied variables were presented. The Chi-square test was used to compare the three universities about the number of professors with Master's degrees and PhD degree included. The KolmogorovSmirnov test was used to compare the production of professors with Master's degrees and $\mathrm{PhD}$ degree regarding the quality of the scientific production in the period from 2008 to 2012 in the different levels of Qualis classification scale of CAPES. It was used the SPSS program (Statistical Package for Social Sciences, 
Inc., Chicago, USA) and the level of rejection of the null hypothesis was set in $5 \%(\alpha \leq 0.05)$.

\section{Results}

The Medicine programs of UEPA, UFPA and UFPB have, respectively, 63, 62, 64 professors in the surgical area. Among them, the ones with Master and PhD degrees are, respectively, 36 (57\%), 38 (61\%) and 24 (38\%). The inclusion and exclusion of those professors in the present study and their distribution through the surgical specialties are presented in the Tables 2 and 3.

TABLE 2- Frequency of Professors of the State and Federal Universities of Para and Federal University of Paraiba versus Academic degree (Master or PhD) (Chi-square test).

\begin{tabular}{|c|c|c|c|c|c|c|c|c|c|}
\hline \multirow[b]{2}{*}{ Total of surgical area teachers } & \multicolumn{3}{|c|}{ UEPA } & \multicolumn{3}{|c|}{ UFPA } & \multicolumn{3}{|c|}{ UFPB } \\
\hline & \multicolumn{3}{|c|}{63} & \multicolumn{3}{|c|}{62} & \multicolumn{3}{|c|}{64} \\
\hline \multirow{2}{*}{$\begin{array}{c}\text { Exclusions (without Academic } \\
\text { degree - Ms or PhD) }\end{array}$} & \multicolumn{3}{|c|}{27} & \multicolumn{3}{|c|}{24} & \multicolumn{3}{|c|}{40} \\
\hline & Masters & $\mathrm{PhD}$ & Total & Masters & $\mathrm{PhD}$ & Total & Masters & $\mathrm{PhD}$ & Total \\
\hline Professors with Academic degree & 22 & 14 & 36 & 22 & 16 & 38 & 6 & 18 & 24 \\
\hline $\begin{array}{l}\text { Exclusions } \\
\text { (without curriculum Lattes) }\end{array}$ & 5 & - & 5 & 4 & - & 4 & - & - & - \\
\hline $\begin{array}{l}\text { Exclusions ( } \\
\text { outdated curriculum Lattes) }\end{array}$ & 3 & 1 & 4 & 5 & 2 & 7 & 2 & 2 & 4 \\
\hline Professors included & 14 & 13 & 27 & 13 & 14 & 27 & 4 & 16 & 20 \\
\hline
\end{tabular}

TABLE 3- Absolute and relative frequency of professor with Masters and PhD per specialty.

\begin{tabular}{|c|c|c|c|c|c|c|c|}
\hline & \multicolumn{2}{|c|}{ UEPA } & \multicolumn{2}{|c|}{ UFPA } & \multicolumn{2}{|c|}{ UFPB } & \multirow[b]{2}{*}{ TOTAL - n (\%) } \\
\hline & Masters & $\mathrm{PhD}$ & Masters & $\mathrm{PhD}$ & Masters & $\mathrm{PhD}$ & \\
\hline Surgery & 2 & 2 & - & 1 & - & 1 & $6(8)$ \\
\hline Cardiovascular Surgery & 1 & - & & 1 & - & 2 & $4(6)$ \\
\hline Gastroenterological Surgery & 3 & 2 & 4 & 3 & 2 & 1 & $15(20)$ \\
\hline Otorhinolaryngology & 1 & 3 & 1 & 3 & - & 1 & $9(12)$ \\
\hline $\begin{array}{c}\text { Reconstructive and Plastic } \\
\text { Surgery }\end{array}$ & - & - & - & 1 & - & - & $1(1)$ \\
\hline Thoracic Surgery & 1 & - & - & - & - & - & $1(1)$ \\
\hline Urologic Surgery & 2 & - & 1 & 1 & - & 2 & $6(8)$ \\
\hline Gynecology and Obstetrics & 3 & 3 & 5 & 1 & 2 & 5 & $19(26)$ \\
\hline Ophthalmology & 1 & 2 & 1 & 3 & - & 3 & $10(14)$ \\
\hline Orthopedics & - & 1 & 1 & - & - & 1 & $3(4)$ \\
\hline TOTAL - n (\%) & $14(19)$ & $13(18)$ & $13(18)$ & $14(19)$ & $4(5)$ & $16(21)$ & $74(100)$ \\
\hline
\end{tabular}


Seventy-four professors, 27 (36.5\%) from UEPA, 27 (36.5\%) from UFPA and 20 (27\%) from UFPB met the eligibility criteria. From 54 professors from Para universities, seven (13\%) of them work in both institutions, being five with $\mathrm{PhD}$ degree and two with a Master's degree. Regarding the specialty, three out of the seven professors belongs to Otorhinolaryngology department, two of Gastroenterological Surgery, one of Gynecology and Obstetrics and one of Ophthalmology. The specialty with the largest number of professor with Academic degree was Gynecology and Obstetrics (26\%), followed by Gastroenterological Surgery with $20 \%$ of the total.

The Table 4 presents the distribution of professors' scientific productions included in this study from 2008 to 2012 in the strata of Qualis classification scale of the area Medicine III of CAPES.

TABLE 4 - Distribution of scientific production of the universities, in the period 2008-2012, according WebQualis CAPES.

\begin{tabular}{|c|c|c|c|c|}
\hline & UEPA & UFPA & UFPB & $\begin{array}{c}\text { TOTAL - } \\
\text { n (\%) }\end{array}$ \\
\hline A1 & 2 & 5 & 3 & $10(5)$ \\
\hline A2 & - & 9 & 2 & $11(5)$ \\
\hline B1 & 2 & 20 & 9 & 31 (14) \\
\hline B2 & - & 2 & 4 & $6(3)$ \\
\hline B3 & 15 & 11 & 8 & 34 (16) \\
\hline B4 & 2 & 48 & 4 & $54(25)$ \\
\hline B5 & 59 & 10 & 1 & $70(32)$ \\
\hline $\begin{array}{c}\text { TOTAL - n } \\
(\%)\end{array}$ & $80(37)$ & 105 (49) & $31(14)$ & $216(100)$ \\
\hline
\end{tabular}

Table 5 shows a comparison between the productions of professors with a Master and $\mathrm{PhD}$ degree.

TABLE 5 - Comparison between professors with Master and $\mathrm{PhD}$ degrees of the three universities, in the period 2008-2012 (Kolmogorov-Smirnov test).

\begin{tabular}{|c|c|c|c|}
\hline & Masters & $\mathrm{PhD}$ & $\begin{array}{c}\text { TOTAL - n } \\
(\%)\end{array}$ \\
\hline A1 & 1 & 9 & $10(5)$ \\
\hline A2 & - & 11 & $11(5)$ \\
\hline B1 & 5 & 26 & $31(14)$ \\
\hline B2 & 1 & 5 & $6(3)$ \\
\hline B3 & 5 & 29 & 34 (16) \\
\hline B4 & 15 & 39 & $54(25)$ \\
\hline B5 & 17 & 53 & $70(32)$ \\
\hline $\begin{array}{c}\text { TOTAL - n } \\
\text { (\%) }\end{array}$ & $44(20)$ & $172(80)$ & $216(100)$ \\
\hline
\end{tabular}

It was noticed that the largest number of publications and the greatest concentration at higher levels (Qualis B1 or higher) were among the ones with $\mathrm{PhD}$ degrees but without a statistical relevance $(\rho=0.074)$. It was also ascertained a more numerous scientific production in UFPA (49\% of the total of publications) and more concentrated at higher levels of Qualis classification scale.

The specialty with the largest number of publications was Otorhinolaryngology ( $29 \%$ of the total of publications); however, $98 \%$ of those publications were in journals classified at Qualis B3 or lower. Gastroenterological Surgery in turn, responsible for $23 \%$ of the total of publications, had $57 \%$ of its publications classified at Qualis B1 or higher (Table 6). 
TABLE 6 - Distribution of scientific production of the three universities, in the period 2008-2012, according WebQualis CAPES Medicine III per specialty.

\begin{tabular}{|c|c|c|c|c|c|c|c|c|}
\hline & A1 & A2 & B1 & B2 & B3 & B4 & B5 & TOTAL - n (\%) \\
\hline Surgery & - & - & - & - & 8 & - & 6 & $14(6)$ \\
\hline Cardiovascular Surgery & - & - & - & 1 & 1 & - & - & $2(1)$ \\
\hline Otorhinolaryngology & - & - & 1 & - & 4 & 23 & 34 & $62(29)$ \\
\hline $\begin{array}{c}\text { Reconstructive and Plastic } \\
\text { Surgery }\end{array}$ & - & - & - & - & - & 1 & - & $1(0.5)$ \\
\hline Ophthalmology & 6 & - & 4 & 1 & 11 & - & - & $22(10)$ \\
\hline Orthopedics & - & - & - & - & 1 & - & - & $1(0.5)$ \\
\hline TOTAL - n (\%) & $10(5)$ & $11(5)$ & $31(14)$ & $6(3)$ & $35(16)$ & $54(25)$ & $70(32)$ & $217(100)$ \\
\hline
\end{tabular}

The most frequent type of guidance was the one about scientific work of completion of undergraduate course (SWCUC) (63\%) (Table 7).

TABLE 7 - Frequency of the type of guidance.

\begin{tabular}{|c|c|c|c|c|c|c|c|}
\hline & \multicolumn{2}{|c|}{ UEPA } & \multicolumn{2}{|c|}{ UFPA } & \multicolumn{2}{|c|}{ UFPB } & \multirow[b]{2}{*}{ TOTAL - n $(\%)$} \\
\hline & Masters & Doctors & Masters & Doctors & Masters & Doctors & \\
\hline PhD & - & - & - & 4 & - & 2 & $6(2)$ \\
\hline Master & - & - & - & 13 & - & 8 & $21(6)$ \\
\hline Residency & 2 & 2 & 4 & 3 & 1 & 20 & $32(10)$ \\
\hline SWCUC & 23 & 46 & 41 & 63 & - & 32 & $205(63)$ \\
\hline Scientific initiation & - & 11 & - & 25 & - & 24 & $60(19)$ \\
\hline TOTAL - n (\%) & $25(8)$ & $59(18)$ & $45(14)$ & $108(33)$ & $1(0)$ & $86(27)$ & $324(100)$ \\
\hline
\end{tabular}

Gynecology and Obstetrics presented the greatest number of guidance of undergraduate and graduate students (35\% of the total), including the supervision of scientific work of completion of undergraduate course, corresponding to $41 \%$ of this specialty. Gastroenterological Surgery in turn presented the largest number of Master and PhD guidance (Table 8).

TABLE 8 - Distribution of student's guidance, per specialty.

\begin{tabular}{|c|c|c|c|c|c|c|}
\hline & PhD & Master & Residents & SWCUC & $\begin{array}{l}\text { Scientific } \\
\text { initiation }\end{array}$ & TOTAL - n (\%) \\
\hline Surgery & - & 1 & 3 & 6 & 11 & $21(6)$ \\
\hline Cardiovascular Surgery & - & 2 & - & 8 & - & $10(3)$ \\
\hline Gastroenterological Surgery & 4 & 11 & 27 & 5 & 14 & $61(19)$ \\
\hline Otorhinolaryngology & - & - & 25 & 20 & - & $45(14)$ \\
\hline Reconstructive and Plastic Surgery & - & - & - & 2 & - & $2(1)$ \\
\hline Urologic Surgery & - & - & 5 & 14 & - & $19(6)$ \\
\hline Gynecology and Obstetrics & 2 & 4 & 22 & 48 & 40 & $116(35)$ \\
\hline Ophthalmology & - & 3 & 25 & 19 & - & $47(14)$ \\
\hline Orthopedics & - & - & - & 6 & 2 & $8(2)$ \\
\hline TOTAL - n (\%) & $6(2)$ & $21(6)$ & $107(33)$ & $128(39)$ & $67(20)$ & $329(100)$ \\
\hline
\end{tabular}




\section{Discussion}

The Brazilian scientific production has increased in the last decades, a fact that is proved by the indexed publications in the Institute for Scientific Information (ISI), SCImago (SJR) and in the Scientific Electronic Library Online (SciELO) ${ }^{9}$. Particularly in medical area, this increase has been expressed by the expansion of graduate programs, the creation of research groups, the number of qualified researchers and publications of scientific papers in indexed journals ${ }^{9-12}$.

To know the academic reality in the surgical area in Brazilian public universities is crucial to try to reduce the inequalities and to increase Brazilian international competitiveness. The North is a region that presents the worst Academic degree index, which probably reflects in a lower quantity of pulications ${ }^{8}$. State of Para has only five CNPq researchers in Medicine whereas the State of Sao Paulo has roughly fifty times more ${ }^{13}$. The shortage of graduate programs in certain regions can influence as the quality of the scientific production as the certification of many surgical professors. The states of Para and Paraiba do not possess graduate programs in the surgical area, a fact that can be related to the low number of publications and surgical professors with Academic degrees.

The Senate Bill No. 706, 2007, alters the article 52 of Law No. 9.394, December $20^{\text {th }}$, 1996, established the guidelines and basis for national education in order to demand minimum specific percentages for professors, with Master and PhD degrees with full-time jobs in the universities. According to this bill, at least $50 \%$ of the professors from Brazilian universities must have Academic degree ${ }^{14}$. In the present study, respectively, 57\%, $61 \%$ and $38 \%$ of the professors in the surgical area from UEPA, UFPA and UFPB have Master and PhD degrees. However, those percentages are only about the professors of the surgical area, not about the total of professors from every university.

Even though there is no statistical difference $(\mathrm{p}=0.074)$, a trend was noticed to a larger production at higher strata from WebQualis CAPES by the professors with PhD degree. According to Velloso ${ }^{15}$, professionals with $\mathrm{PhD}$ degree tend to present a profile more geared towards research and teaching, while the ones with Master's degree tend to play a role in the professional life or in the private area, showing that there is a need to take measures which encourage them to obtain a $\mathrm{PhD}$ degree. The variable that best suits the increase of Brazilians in indexed papers in international databases is the rise of the number of $\mathrm{PhD}$ students ${ }^{16}$.

The specialty with the largest number of professors with Academic degree was Gynecology and Obstetrics (26\%), followed by Gastroenterological Surgery (20\%) and this reflects in the production of these specialties. Otorhinolaryngology and Gynecology and Obstetrics were responsible for the greatest number of publications (respectively $29 \%$ and $27 \%$ of the total of publications). However, 91\% of production of those two specialties occurred in Journals Qualis B3 or lower.

Gastroenterological Surgery in turn, responsible for 23\% of publication total, had its production concentrated at higher strata of Qualis, with 57\% of publications in B1 or higher. One of the reasons for this highlighted position is the participation of professors from this specialty in graduate programs in fields such as Molecular Biology, Genetics and Oncology. Gastroenterological Surgery was the specialty with the largest number of Master and $\mathrm{PhD}$ degrees concluded student's guidance, confirming the close relation between graduate program and scientific production. This fact diverges from the national reality, since Ophthalmology is the surgical area that mostly publishes articles in Brazil: there were 914 publications between 2008 and 2010, corresponding to $38 \%$ out of the 2.289 publications in surgical area in the period ${ }^{17}$.

Concerning the type of supervision, SWCUC was the most frequent guidance in the studied universities. The region does not have any graduate program in the surgical area, which contributes to the small participation of surgeons in thesis guidance. Professors who work in universities of the State of Sao Paulo in turn have greater opportunities to supervise Master dissertations or $\mathrm{PhD}$ theses, given that $78 \%$ of graduate programs from the surgical area are in this State ${ }^{18}$

The solution to reduce the inequalities among Brazilian States and regions is not only relocating financial resources but also creating and establishing graduate students in these regions, offering subsidies for those researchers ${ }^{10}$. Nevertheless, the regions with lower contingents of professionals with Master and $\mathrm{PhD}$ degrees tend to struggle, due to insufficiency of qualified human resources to create and support graduate programs ${ }^{19}$.

If no measures are taken to revert this scenario, a vicious circle will end up remaining and there will always be graduate programs in the South-Southeast line, culminating in a greater concentration of professionals with Master and $\mathrm{PhD}$ degrees in those regions and a lack of them in the other ones, which makes the creation of new programs hard ${ }^{20}$.

Public measures that encourage the creation of new graduate programs in the surgical area are necessary and have been carried out by CAPES, mainly in the North and Northeast regions, in order to foster a scientific and technological development of those regions and reduce the asymmetries among the different regions in the country. 


\section{Conclusions}

The specialties Gynecology and Obstetrics and Gastroenterological Surgery from the State University of Para (UEPA), Federal Universities of Para (UFPA) and of Paraiba (UFPB) presented the greatest number of professors with academic degrees. Gastroenterological Surgery presented the largest scientific productions at higher strata of WebQualis CAPES classification and also the largest number of Master and $\mathrm{PhD}$ directed.

\section{References}

1. Fávero MLA. A Universidade no Brasil: das origens à Reforma Universitária de 1968. Educar. 2006;28:17-36.

2. Administrative Development Foundation. [Fundação do Desenvolvimento Administrativo (FUNDAP) web site]. Available from: http://www.fundap.sp.gov.br/rm. [Accessed December 01, 2012].

3. Souza VCT, Goldenberg S. Pós-Graduação sentido estrito em medicina: avaliação dos egressos do Curso de Pós-Graduação em Técnica Operatória e Cirurgia Experimental da Escola Paulista de Medicina. Acta Cir Bras. 1993;8(4):190-9.

4. André M. Desafios da pós-graduação e da pesquisa sobre formação de professores. Educação \& Linguagem. 2007;10(15):43-59.

5. University of Sao Paulo. [Universidade de São Paulo (USP) web site]. Available from: http://www.fm.usp.br/posclinicacirurgica. [Accessed December 01, 2012].

6. Brasil. Coordenação de Aperfeiçoamento de Pessoal de Nível Superior (CAPES). Available from: http://www.capes.gov.br/sobrea-capes/plano-nacional-de-pos-graduacao. [Accessed December 01, 2012].

7. Medical Schools in Brazil. [Escolas Médicas do Brasil web site]. Available from: http://www.escolasmedicas.com.br. [Accessed December 02, 2012].

8. Teixeira RKC, Gonçalves TB, Botelho NM. Análise Quantitativa de Pós-Graduandos em Ciências de Saúde no Brasil: Perfil por Estados. UNOPAR Cient Ciênc Biol Saúde. 2012;14(3):183-8.

9. Guimarães JA. A pesquisa médica e biomédica no Brasil: comparações com o desempenho científico brasileiro e mundial. Ciênc. Saúde Coletiva. 2004;9(2):303-27 .

10. Bortolozzi F, Gremski W. Pesquisa e Pós-graduação brasileira assimetrias. RBPG. 2004;1:35-52.

11. Rasslan S, Barata RB, Rodrigues JJG Pós-graduação, produção intelectual e veículo de publicação. Rev Col Bras Cir. 2003;30(1):13.

12. Mugnaini R, Jannuzzi PM, Quoniam L. Indicadores bibliométricos da produção científica brasileira: uma análise a partir da base Pascal. Ci Inf. 2004;33(2):123-31.

13. Martelli-Junior H, DRB, Quirino IG, Oliveira MCLA, Lima LS, Oliveira EA. Pesquisadores do CNPq na área de medicina: comparação das áreas de atuação. Rev Assoc Med Bras. 2010;56(4):478-83.

14. Senate Bill 706, 2007. Available from: http://www6.senado.gov.br/ mate/servlet/PDF. [Accessed December 02, 2012].

15. Velloso J. Mestres e doutores no país: destinos profissionais e políticas de pós-graduação. Cad Pesq. 2004;34(123): 583-611 .

16. Guimarães R. Challenges of postgraduate human health programs in
Brazil. Rev Saúde Pública. 2011;45(1):1-13.

17. Ministério da Ciência, Tecnologia e Inovação. Fundação de Amparo à Pesquisa do Estado de São Paulo. Indicadores FAPESP de Ciência, Tecnologia e Inovação. São Paulo: FAPESP; 2011.

18. Ministério da Ciência, Tecnologia e Inovação. Conselho Nacional de Desenvolvimento Científico e Tecnológico (Brasil). Relatório de avaliação trienal 2007-2009. Brasília: Conselho Nacional de Desenvolvimento Científico e Tecnológico; 2010.

19. Balbachevsky E. A pós-graduação no Brasil: novos desafios para uma política bem sucedida. In: Brock C, Schwartzman S. Os desafios da educação no Brasil. 1ed. Rio de Janeiro: Nova Fronteira; 2005. p.275-304.

20. Kuenzer AZ, Moraes MCM. Temas e tramas na pós-graduação em educação. Educ Soc. 2005;26(93):1341-62.

${ }^{1}$ Research performed at Para State University (UEPA), Para Federal University (UFPA), Paraiba Federal University (UFPB) and Sao Paulo Federal University (UNIFESP), Brazil 